\title{
Self-Building Courses of Solar Heat Collectors as Sources of Consumer Empowerment and Local Embedding of Sustainable Energy Technology
}

\author{
Mikko Jalas, Helka Kuusi and Eva Heiskanen
}

\begin{abstract}
Self-building courses have been identified as a stimulus for user innovations, local embedding and diffusion of renewable energy technology. In this paper we explore the Finnish solar heat collector self-building courses. Our empirical material consists of field observations, interviews with teachers and a survey of participants since the early activities in late 1990s. Our findings show that course participants have started to follow energy discussions, collect information and actively advise others. Participants view themselves as increasing capable actors in renewable energy. They have also begun to engage in energy saving and renewable energy at home on a wide front. The fact that only $41 \%$ have installed their collector points to the importance of timing but also to the way in which self-building courses serve as a first step into renewable energy. Overall our results indicate that self-building courses offer possibilities for material engagement that has outcomes beyond the immediate objectives of the course.
\end{abstract}

Keywords: solar heat collectors, self-building, material engagement

\section{Introduction}

Energy provision has been historically based on centralized systems, in which energy users have limited involvement. The current interest in micro-generation is challenging this situation. However, the adoption of new technologies and roles in diverse local contexts requires significant adaptation and transformation of both technologies and contexts. We explore solar heat collector self-building courses as sites of such transformation.
Self-building courses have been identified as a stimulus for user innovations and local embedding of the technology in Austria (Ornetzeder \& Rohracher, 2006). They have also been identified as a key diffusion mechanism that at times has been comparable to the commercial supply of solar heat collectors (Ornetzeder, 2001). Apart from promoting diffusion and engaging new users for solar heat collectors, there is also literature suggesting that energy-related self-building activities can empower consumers and help them take a 
more active role in energy systems (Darby, 2006). More generally, courses can also be understood as sites of material engagement in which public politics is enacted. However, there is limited research on selfbuilding courses outside the Austrian context, and particularly the wider impacts of such courses remain unclear. Hence, our research is explorative and aims to uncover the evolution of course activities in Finland, the participants' interests, experiences and changes in practices following such courses, and the potential impacts of self-building courses on local interest and uptake of solar technologies.

We conceptualize self-building courses as material settings in which politics and publics are mobilised (Marres, 2009; Marres \& Lezaun, 2011). This suggests that selfbuilding activities have impacts beyond the immediate scope of the course (i.e., the building of solar heat collector collectors for the participants). We are interested in both the way mobilization takes place at the courses and in the effects of this mobilization. The latter include changes in other household practices and changes in relations to technology as such and energy technologies in particular. Moreover, on the community level, we anticipate changes in overall engagement with renewable energy. Based on our findings, we suggest avenues for further and more specified research and experimentation.

The Finnish solar heat self-building activities lean explicitly on the Austrian experiences, and yet differ from them in important ways. The Finnish courses are not self-organised citizen initiatives, but organised by vocational schools, folk high schools and entrepreneurs. Yet, the Finnish courses lack public recognition and the institutional support. Solar heat collectors have also evolved since the Austrian courses in the 1990s and self-building might be less cost-effective today. Hence we can expect that the motivations to participate in courses as well as the outcomes in terms of wider dissemination are different in Finland from the Austrian experiences.

The paper is structured as follows: We continue by first discussing user involvement in technology development and, in particular, the role of self-building activities. Having established this background we set the research questions that address the Finnish self-building courses. Thereafter we introduce our empirical material and discuss both the development and scope of Finnish self-building activities as well as the motivation and the wider impacts of participation in these courses.

\section{Solar Heat Collector Self- Building Courses as Sites of Material Engagement}

The involvement of users in the development of new technologies is a popular topic in science and technology studies, albeit approached from different perspectives. The social construction of technology approach has focused on how particular early user groups shaped technological development paths (Bijker et al., 1986). Following from this, there have been attempts and calls for 'opening up' the early stages of technology development to a wider array of different kinds of users through various discursive forums and practices (Rip et al., 1995; Schot, 2001; Heiskanen, 2005). User involvement is stressed because different configurations of technological systems have political consequences for which kinds of users are empowered or disenfranchised.

However, diverse users can also get engaged in technology development through action rather than discussion or conventional political means (Marres, 2009). User innovation and the role of lead users who invent to meet needs that are not met by the current market offerings are 
one example of practical engagement (von Hippel, 2005; Ornetzeder \& Rohracher, 2006). In particular, when examining the development of renewable energy technologies, practical engagement and social mobilization is viewed as crucial for the acceptance and local embedding of new technologies, as well as for their diffusion to other contexts (Raven et al., 2008). More generally, Marres and Lezaun (2011) suggest that individuals who experiment with technology form engaged material publics. The use of technology and a public report of one's material entanglements results in 'public intimacy' and in material engagement that is at the same time public and political as well as material and intimate.

What is the nature of the spaces in which political leverage is acquired and accomplished through practical and material engagement, and to what extent and in which respect might self-building activities be political? Marres and Lezaun (2011) agree on the political facet of ongoing experimentation and technology development by lead-users but also point to the efforts required in and consequences of material engagement. These efforts signal that technologies have real conditions and consequences and are 'doable' in various degrees (Marres \& Lezaun, 2011). That is, the private joys and struggles of material entanglements carry a political weight when brought into public. From this perspective, experimentation refers to a sensual probing and trial of new technologies that results not (only) in new knowledge but also in a reconfiguration of socio-material entities (Marres, 2009).

Our conceptualization of selfbuilding courses as material settings in which politics is performed suggest a particular line of research. Firstly, we understand experimentation as the sensual appropriation of new technology that involves both changes in the design of, for example, solar collectors but crucially also in the way the devices are to be talked about, understood, assembled, installed and combined with other existing technologies. This is to say that experimentation does not necessarily leave traces in the product design, and that material engagement is to be assessed not only in terms of user innovations. Experimentation and assembly are interesting also as modes of material engagement and as 'doing' or inserting the self in the technology. Secondly, one needs to understand the way that these efforts are made public. Sharing via Internet blogs (Marres, 2009) and Internet forums (Hyysalo et al., 2013) are special cases of sharing user innovations. Self-building courses imply different media and particular collegial publics that include other course participants and alumni as well as future participants.

The role of practical action by users and user movements in the political struggle over system design is particularly highlighted in the case of open source software (e.g. Holthgrewe \& Werle, 2005). Here, the struggle is explicitly played out through a counter-culture that focuses on the concrete development of an alternative (and better) system to that represented by the dominant market players. In the case of open source software, the publicity of efforts is at the very heart of this activity. However, research on motivations for users to participate in open source software development reveals a mixture of interests, some of which are pragmatic, some personal, some professional and only some explicitly political (Freeman, 2007). Hence, we too approach the political nature of material engagement as emergent rather than as intentional and explicitly organized.

The topic of user-driven technological counter-cultures has re-emerged in a debate over low-carbon energy systems and the 
types of roles that various systems configure for users (e.g. Hoffmann \& High-Pippert, 2005). Small-scale renewable energy has often been presented as a counter-force to large-scale centralized energy systems and the related economic and political systems. Indeed, user involvement and, to a degree, also collective self-building are frequent in low-tech solutions such as solar heat collectors and small scale wind turbines ${ }^{1}$. Recent research has also suggested that a decentralized energy system based on active user involvement - i.e., via micro-generation of energy - could serve to empower users more than the current centralized system does. This argument builds on (fairly scattered) evidence on small groups of users who produce their own heat and power and are more aware of their energy consumption than those who solely rely on the dominant centralized energy system (Keirstead, 2007).

Some of these issues have already been examined in connection with solar heat collector self-building courses. Ornetzeder (2001) and Rohracher and Ornetzeder (2006) examined the solar self-building course movement in Austria and found it had a significant role in not only early technology development, but even more in the diffusion and acceptance of solar heat collectors (self-built and commercially manufactured) in Austria. In addition to the practical skills that participants gained, the peer-to-peer learning and social exemplars set by these courses were found to be influential. Ornetzeder (2001) also points out the way that participants gained increasing scope to act and further engage new people in solar heat collector selfbuild courses. Yet these previous studies on self-building do not elaborate on how the courses influence participants' relations to energy and technology.

Despite extended efforts, we have not been able to locate wider research on selfbuilding courses of renewable energy technologies. Citation databases contained no clear stream of research connected to the Austrian studies mentioned above. More generally searching for 'course', 'training' or 'hobbyist' activity in renewable energy technology with Google Scholar and in Science Direct yielded no results pertaining to organized self-building activities. There is thus an obvious need to focus on selfbuilding courses and, in particular, on their abilities to mobilise and empower diverse participants.

The self-building courses organized in Finland represent an attempt to 'import' the Austrian experience, but have gained a distinctive local flavor, as will be shown in the following. We specify our research questions as following. In terms the relocation of selfbuilding courses, it is interesting to see (1) whether similar phenomena have the capacity to survive in other cultural contexts with different traditions, and whether they have the capacity to engage a wide crosssection of the population in one way or another. One question here is whether the self-building courses in Finland rely on a relatively narrow segment of 'deep green' people, or whether they manage to offer participants some immediate and more personal benefits, as they did in Austria (Ornetzeder, 2001).

A related question pertains to the courses' capacity for survival and evolution. Ornetzeder and Rohracher (2006) stressed the importance of the self-building courses at the early stage of technological diffusion, when manufactured packages were expensive and still left room for improvement. The courses started to spread in the Finnish context at a much later stage and never reached the level of nation-wide institutionalization that was experienced in Austria. Hence, we ask: (2) Is there a mechanism for social replication and evolution in the Finnish courses that allows them to grow, share experiences and evolve 
as the technology and market evolves and matures?

If and when DIY courses can survive, their outcomes are of key relevance. We ask (3) whether the courses can serve to promote acceptance and local embedding of a novel technology through peer-to-peer learning, social examples and social mobilization. When examining social mobilization, however, we want to be sensitive to the course context and the bodily engagements, experimentation and the resulting more implicit and object-centered activism and involvement (Marres, 2009). We are thus interested in learning (4) whether participants gain more from their practical engagement with solar heat collectors than merely a new piece of equipment and what is the nature of activism that results from the experimentation and material contacts at self-building courses. Overall we aim to contribute to the 'decentralized energy systems' hypothesis by examining whether participants become more aware of their energy use and more capable and active in energy policy as a result of the courses and the practical engagement therein.

\section{Empirical Material of the Study}

This study is based on several types of empirical material concerning Finnish solar collector self-building courses. We started exploring the field by making initial contacts with those teachers who we could identify on the internet and those that were known to the national solar energy association. Once these contacts had been established we began to interview teachers and course organizers. Altogether six teachers and five course organisers were contacted and interviewed. Some of these teachers and organisers had been active already in the early 2000s and some were newcomers. In addition, one of the authors enrolled in a five-day course in June 2012 and interviewed and observed course participants. This course was organized in the municipality of Eurajoki and we refer to this part of the evidence as the 'Eurajoki course'.

In addition to interviewing teachers and organisers, we conducted a survey among former course participants, which was organized in the following way. We first contacted course teachers and organizers, and a total of 13 organizers agreed to help us. They delivered part of the surveys (available in both Finnish and Swedish) themselves electronically or through the post to former course participants. Some of the teachers and organizers agreed to give us the contact information, and we sent out the surveys. A total of about 700 questionnaires were distributed. The exact number is somewhat uncertain because some of the questionnaires were distributed directly by the organizers. However, this approximates the total number of people who have participated in organized selfbuilding courses for solar heat collectors in Finland. As time has passed, especially e-mail addresses are no longer current, so some of the questionnaires might not have reached the former course participants. We gained 134 responses (112 in Finnish and 22 in Swedish). The total response rate is hence about $19 \%$, which is likely at least partly due to outdated contact information.

In addition, two guidebooks for solar heat collector self-building from the years 2000 and 2006 have served as secondary material.

\section{Self-Building Courses for Solar Heat Collectors in Finland}

\section{Self-building courses in Finland}

Solar heat collectors remain a marginal phenomenon in Finland. While energy efficiency, renewable energy and the benefits of distributed energy generation have been discussed actively, the focus 
of these debates has not been on solar thermal systems. Consequently, also the share of dwellings that make use of solar heat collectors is low. According to the European Solar Thermal Industry Federation (ESTIF, 2012), the total installed capacity in Finland in 2011 was less than $33000 \mathrm{~m}^{2}$ and about $23000 \mathrm{~kW}$, which can be estimated to amount to about 5 000-8 000 units (assuming an average size of about 4-6 $\mathrm{m}^{2}$ ). These figures point roughly to a diffusion level of $0,5 \%$ in the Finnish stock of detached houses. In spite of the low rate of adoption in general, and compared with it, the self-building courses in Finland are not a marginal phenomenon. As mentioned we came up with an address list of more than 700 course participants over a time period that starts from the late 1990s.

One of the key staring points for the Finnish courses in the late 1990s was an EUfunded research project aiming to make use of the Austrian experiences of self-building courses and trying to launch similar activities in Finland (Faninger-Lund \& Lund, 2000). This resulted in purposive dissemination activities. Some of the early courses took place at Kronoby Folk High School in the Ostrobothnia region and aimed, following the Austrian example, to educate new teachers to run courses elsewhere. Furthermore, the assembly and installation of solar collectors has been documented in leaflets and guidebooks (Faninger-Lund \& Lund, 2000; Lindström, 2006). A second, less documented development concerns the frequent courses organized by a single teacher who had emigrated from Germany to Finland in 1999 and had a background in counselling private households about solar heat installations. Another key teacher, an in-house tool manufacturer of a large industrial company, began his teaching activity in 2006, and has organized courses for roughly 200 participants. These two persons have taught the majority of the courses that we have been able to locate in Finland.

\section{Motives to organise and teach courses}

In Austria, Ornetzeder (2001) reports that individual courses were organised and set up by existing social groups that had traditions in collective activity. The Austrian association of renewable energy supported such local organization with knowledge and with a toolkit for manufacturing collectors. Despite an attempt to replicate the Austrian course concept, the Finnish courses are not organised based on such bottom-up initiatives of householders. Rather, folk high schools and regional semi-public energy efficiency agencies have acted as organisers and marketed the courses for individuals as they do with any other courses.

Based on our interviews with teachers and the institutions that organize these courses, it seems that enthusiastic teachers have been the main initiators for new courses. This implies that courses have been organized on an ad-hoc basis, and the continuity of the activity has been based on these individuals. Altogether, most of the schools appear to play only a minor role and the (few) teachers more of a decisive role.

However, schools have recently begun to take more strategic approaches towards solar heat collectors. The courses in Eurajoki were for example established in 2010 because they were viewed to fit the course portfolio and complement the image of the school. As the coordinator states: "These are courses that we manage to fill up, for sure. For once, the majority of participants are men unlike our other courses. And the image is progressive if you compare it with needlework and wooden boatbuilding." The way that vocational schools, folk high schools and polytechnics are perceiving solar heat collectors as a fitting part of their course activities signals a different dissemination channel from the Austrian 
case. However, despite the more strategic and institutionalized logic towards solar heat self-building courses, most of the organizers continue to rely on independent teachers. The availability of teachers seems to be a critical resource.

The role of regional energy agencies has been to encourage folk high schools or vocational schools to engage in organizing a course and to contribute to the theoretical teaching, i.e. basics of solar heat collectors. They appear to have been critical in triggering the involvement of the schools by drawing in public funding, providing basic knowledge and brokering teachers.

The motives and positions of the teachers involved vary. The two teachers that have run at least half of all self-building courses are both entrepreneurs who sell their services as teachers, import and sell supplies and provide counselling for system design. Teachers who have been involved for a longer period perceive a change in the role of the courses. In the early 2000s, people were motivated by the low cost of self-building. Now one of the teachers regards this era as history and rather emphasizes the need to educate participants to make good choices in the commercial markets. Consequently, he no longer runs self-building courses.

Teachers who have been involved for a shorter period of time did not perceive the low prices of commercial solutions as problematic. Rather, they anticipate wider effects of empowerment and claim that people no longer are bound to think about pay-back time or feasibility in general, but engage more whole-heartedly in the activity and are keen to collect independent and truly "free" energy, as they label solar heat. Accordingly, these teachers view the courses as fun, social gatherings during which the tasks of assembly are rotated and the collectors come about as a result of collective effort. The teacher in Eurajoki views the smooth flow of tasks as his major concern: he recognizes that people have different skills but hopes to avoid people that are "all thumbs", because then time is consumed at instruction and the work is ultimately left for others to do. Similarly, he also perceives too much theoretical interests as problematic because "collectors don't get done only by talking".

\section{The course contents and collector types}

The content of a solar heat self-building course and the learning and engagement opportunities it offers depend on the selected collector types, on the number of collectors to be built during the course and on the aims of the course in terms of wider learning. All of these have varied in the history of the courses in Finland. The first guidebook on self-built solar heat collectors (Faninger-Lund \& Lund, 2000) is far more open in terms of technical solutions than the latter course book (Lindström 2006). Leaning on the Austrian course concept, Faninger-Lund and Lund (2000) review the solutions for integrating collectors in the roof structures. The dimensions of the collectors also remain flexible. In the latter guidebook of, the design is already more specified. The dimensions of the model developed in Ostrobothnia are roughly $2200 \mathrm{mmx} 1000 \mathrm{~cm}$. It is built around an aluminium absorption element that is housed in a separate casing. The material of the casing was first wood, but changed to aluminium profile later. The heat transfer from the absorption plate to the system of water circulation is currently done with copper pipes and soldered joints, although aluminium piping and pressure joints have also been on trial. In general, it seems that the Ostrobothnia model is relatively wellfitted for the self-building course concept. The flow of assembly consists of separate tasks and erring in one point is not critical overall but can be corrected. Furthermore, the critical feature of the collector - the 
soldered joints - can be simply tested at the end of the process.

The above-mentioned improvements witness to a constant effort to improve the collector design. This story of the evolution of the collector also served at the Eurajoki course to create legitimacy for experimenting and collective ownership of the collector. In 2012, we were "to try out polyurethane insulation" and new tools for bending copper pipes. The collective identity and the public nature of the efforts were further prompted by site visits to and presentations given by participants of previous courses.

The courses need to attend to the elementary techniques such as cutting aluminium, drilling, soldering, riveting, painting as well as testing that are needed to bring about a collector unit. However, participants need much more knowledge of how to integrate solar collectors into other technical systems, where to install collectors, what are the proper dimensions of the collectors and how to service and maintain them. Among the course participants in Eurajoki in 2012, some participants viewed themselves as capable of also installing the collector units they had built on the course. However, participants more commonly felt that they only needed to understand solar heat well enough to instruct the plumber to do the work. Nevertheless, the basic engineering of the heating systems and the right dimensions of each element in the system seemed to rest in knowledge that was (expected to be) available through the course. Despite this, the course organisers in Eurajoki had decided during their threeyear activities to teach less 'theory' during the course and use the classroom only for coffee breaks.

The length of the courses has varied. While the lengths of the courses based on the Ostrobothnia-model has been five days, the bulk of the courses that have been based on the more industrial design have been shorter. The teacher of these courses has attempted to compress the course into two days, during which Friday evening is spend on intensive theoretical teaching and Saturday on assembling one or few collectors to demonstrate the assembly. These courses aimed to exemplify solar heat rather than at the benefits of 'massproduction by amateurs,' which is the case in the other courses. Apart from this matter of principle, the compressed course schedule is motivated by the fact that participants travel from long distances. Against this, the folk high schools that typically also offer lodging services have been ideal sites to organize the longer courses based on the Ostrobothnia-model.

This short view on the institutions and teachers that are involved in organizing the courses shows diverse motives. In our data, we find two distinct schools of thought and two personal histories that make a difference in how courses are run and what kinds of engagement take place. One of the teachers has immigrated with knowledge and experience of serving as an intermediary between commercial actors and the consumers. The other has brought in manufacturing skills and sought to develop a collector type that is less based on commercial components, and rather results out of the joint activities of lay people. The institutions that have played a significant role include both regional energy agencies and folk high schools. The energy agencies have a mandate to promote renewable energy and in addition they have sought to support the local economy. The schools on the other hand have been engaged in order to make good use of their ample available space as well as to gain a positive and progressive image. 


\section{The Motives and Interests for Participating in Solar Self-Building Courses}

Despite the low price of commercial solutions, self-building courses still remain highly popular in Finland. This prompts the question of why people participate in self-building courses: Why to get involved in solar heat in the first place and why to join in a collective effort of self-building? We begin below with some observations from the previous literature on self-building activities, then report the insights from participant observation at the Eurajoki course and finally the results of the survey. Our survey was designed to take into account the multiple motives and rationalities that we had found in the literature and in the first-hand participant observation in the Eurajoki course and interviews with course participants, who also had a chance to comment on our survey questions.

\section{The motives to engage in self-building}

The rise of consumer home DIY, i.e., selfmade home improvements, has stimulated the curiosity of social scientists: why do people who can afford to contract services choose to make improvements themselves, given that the work is not even always perceived of as enjoyable (Watson \& Shove, 2008). Watson and Shove (2008) stress the recursive relation between products, projects and practices in DIY home improvement: the supply of cheap power tools has served to engage new practitioners, whereas projects once started have their own momentum. An explorative study by Wolf and McQuinty (2011) came up with several categories of motives. Some relate to the outcome itself and the desire for customized or unique products, or concerns about the quality and availability of commercial products and services, or the economic benefits of DIY. Others relate to identity enhancement: the empowerment gained from successful accomplishment of a project, personal fulfilment from craftsmanship, and belonging to a DIY community.

In the case of solar heat collector selfbuilding group work, there might also be a broader a range of driving forces. Ornetzeder and Rohracher (2006) note that the low cost of obtaining products contributed to the popularity of the Austrian solar self-building courses, as well as the personal advertising by other users and the social motives to join a group in the neighbourhood. In addition, they stress that work in a self-building group can be tied up with broader social aims such as environmental protection or regional development. Palm and Tengvard (2011) examined the motives for the adoption of small-scale self-assembly micro-generation equipment such as solar panels and small wind turbines in Sweden. They found that some households did this to reduce fossil fuels use, others to display environmental consciousness or set an example to others, and yet others to protest against "the system" and achieve a degree of self-sufficiency.

Motives proved a mixed bunch also at the Eurajoki course. An overriding theme was the desire to be independent of big energy companies and to "harvest" or "catch free energy". Both self-building and the very technology of solar heat collectors fit this aim as collectors are viewed as durable and maintenance free. Pushing the point, free energy was perceived as a way to "give the finger" to the large energy companies. However, the notion of "free energy" also suggested that householders wanted to keep their distance from the state. Participants thus, less provocatively, speculated about a gloomy future in which government intervenes in the collection of free energy and imposes a collector levy. It is interesting to note the mismatch between this anarchic facet of distributed 
energy generation and, on the other hand, climate change mitigation as a collective coordinated international effort. Strikingly, at Eurajoki there was a lot of discussion about free energy, but little if any talk about climate change or carbon footprints.

"Cheap energy" was another and distinct way to understand the motives of participants. Course participants were priceconscious, comparing the prices of different heating technologies for domestic use and the different alternatives of collecting and using solar heat. All participants seemed convinced that solar heat is an increasingly competitive and feasible technology to integrate into heating systems. Yet, at times, the argument surfaced that commercial collectors could be delivered home for the price of the materials of self-building (the material fee of the course was 350 euros/ each collector unit and the course fee 240 euros). Thus while solar energy was in general regarded as cheap, this cost calculus was not extended to the course activities. In a similar vein, the teachers and the participants downplayed efforts to improve the efficiency of the collector by more advanced manufacturing technology. Such fine-tuning of the technology and "going beyond the decimal point" was deemed irrelevant.

The logic of self-building at the Eurajoki course was also built on the merit of selfbuilding as such. People had chosen to participate in the course because they wanted to learn more about solar heat and personally and materially engage in building the collector as a handiwork project. As the time of the course was late June, working participants were using their holidays to participate in the course. In addition there were many pensioners and self-employed people with more flexible time. Yet each participant had had to make some kind of arrangement to find room for the course, and some needed to negotiate course demands with the demands of their professional life. It was evident that the participants were also motivated to participate in the course rather than just to get the collector as the final output of the work. The social, collective nature of the course was enacted by not talking about how many collector units each participant was "making" but how many they are "taking" out of the collective achievement, ranging from one to five. Moreover, participants also made collectors for an elderly man who could not participate in the course due to an accident. Overall, the logic of self-building seems to depend both on protecting the space from overt cost comparisons, on justifying low-tech solutions and on the positive aspects of the collective work: running good conversations, excelling in skills and enjoying the efficacy of dividing work.

From a diffusion point of view, it is not only the motives as situated experiences or forward-looking aspirations that matter. It is equally interesting to look at the paths that have led people to participate and thereby follow the idea of Watson and Shove (2008) that self-building activities have momentum of their own. These paths of participation are marked by previous choices of heating systems, by infrastructure changes, by contacts in people's social networks and, among others, by occupational encounters with solar heat. The field notes from the Eurajoki course in table 1 report a wide variety of pathways. 
Table 1. The occupational backgrounds and particular pathways of engagement of the course participants (pseudonyms) in the Eurajoki course.

\begin{tabular}{|c|c|}
\hline $\begin{array}{l}\text { Otto, metal worker } \\
\text { currently driving a lorry }\end{array}$ & $\begin{array}{l}\text { Has a pellet burning system. Has been working in Denmark and seen lot } \\
\text { of houses with collectors. Has also started to collect price information } \\
\text { in Denmark. During the course, repeatedly states that we are quickly } \\
\text { running out of oil and need substitutes. }\end{array}$ \\
\hline Aleksi, farmer & $\begin{array}{l}\text { Has a pellet burning system. Has worked on a mission in Africa and } \\
\text { seen solar collectors there. Has also been on the previous year's course } \\
\text { and is now here for } 8 \mathrm{~m} 2 \text { more. Like Otto, mentions an 'extreme' solar } \\
\text { house in the nearby city of Pori. }\end{array}$ \\
\hline $\begin{array}{l}\text { Johannes, retired from } \\
\text { being an in-house } \\
\text { proto-maker at a car } \\
\text { factory }\end{array}$ & $\begin{array}{l}\text { Has a ground source heat-pump, which he regards an excellent choice } \\
\text { and regrets he did not do it earlier. Plans to somehow install solar heat } \\
\text { for his summer cottage that has been recently connected to the public } \\
\text { water supply but has no electricity supply. }\end{array}$ \\
\hline $\begin{array}{l}\text { Ingrid, woman } \\
\text { entrepreneur, } \\
\text { hairdresser }\end{array}$ & $\begin{array}{l}\text { The husband recently switched jobs and could not get a leave to } \\
\text { participate although had enrolled. The husband is an 'inventor' type. } \\
\text { They have a wood chip burner that consumes “immensely" (100m3). } \\
\text { Solar heat is sought for due to its convenience. Ex-neighbour has been } \\
\text { on a previous course and talked Ingrid's husband into participating. }\end{array}$ \\
\hline Oskari, retired & $\begin{array}{l}\text { Has electric heating. He was not sure where or how to use the panel, } \\
\text { and is only getting a 'half' of a single panel together with his friend } \\
\text { Kaarle whom he convinced to participate as well. Knows a progressive } \\
\text { solar house in the region. }\end{array}$ \\
\hline $\begin{array}{l}\text { Kaarle, worker at a large } \\
\text { coal-fired power plant }\end{array}$ & $\begin{array}{l}\text { Has old collectors in his garage. He has bought these from a client for } \\
\text { whom he was making a renovation and who got new panels. Friend of } \\
\text { the other participant, Oskari. }\end{array}$ \\
\hline $\begin{array}{l}\text { Tomi, restaurant chef at } \\
\text { a cruiser ship }\end{array}$ & Has been previously at the Eurajoki school to build a wooden boat. \\
\hline $\begin{array}{l}\text { Elisa, woman } \\
\text { entrepreneur, organic } \\
\text { catering service }\end{array}$ & $\begin{array}{l}\text { Lives in a house that is under a decommissioning threat. Reasons that } \\
\text { panels are easy to take with her if she needs to move. The person who } \\
\text { later suggests that we should install handles on the panels to make } \\
\text { handling easier. }\end{array}$ \\
\hline $\begin{array}{l}\text { Arne, retired from the } \\
\text { army }\end{array}$ & $\begin{array}{l}\text { Takes lot of pride in having designed and built his house all by himself. } \\
\text { His brother has solar heat collectors. }\end{array}$ \\
\hline
\end{tabular}

\section{Motives and backgrounds documented in the survey for Finnish participants of solar self-building courses}

As we stated earlier, we identified over 700 participants of solar collector selfbuilding courses in Finland. Next we turn to our survey results and ask whether the Eurajoki experiences describe a general pattern. Among our respondents $(n=134)$, the average age is relatively high (Table 2), even though the youngest participant was aged 24 and the oldest $81^{2}$. Most of them are men: only 7 respondents were women, and this reflects the reality in the courses as far as we learned from the interviews with teachers. However, only less than one-third of the participants worked or used to work with building systems (e.g. builder, architect, HVAC installer). More commonly, people had other lines of work, such as teachers, farmers, or some other, technical occupation. Most of them lived in a detached house. At the time of our study, $44 \%$ were pensioners. Participants were active in several respects: many had previously participated in another kind of 
self-building course and a large share was also active in local politics. The respondents mainly $(70 \%)$ consists of people who have attended the longer self-building version as opposed to the short two-day course and many of them (47\%) had attended the course during the last few years, after 2009.

More than half $(53 \%)$ had planned to install a solar heat collector in their own property. However, few of them had much background knowledge of solar heat before enrolling in the course: only $16 \%$ had collected information on solar thermal products in the market and only $13 \%$ had familiarized themselves with actual installed solar thermal systems.

Often, the participants come to the courses from a relatively wide area - i.e., not from the same village. Hence, the social context of the Finnish solar self-building courses is somewhat different from the Austrian ones (Ornetzeder, 2001). Most participants do not appear to have actively sought out the course, either, as only $14 \%$ found the course on the Internet. Many $(50 \%)$ had found the course announcement in the daily newspaper, and almost onethird had found it in the course providers' catalogue (which are often distributed to all residents in the locality). Less than onefifth had learned about the course from an acquaintance or friend or some other personal source. As pointed out in table 1, at Eurajoki there were several people who had some experience or knowledge of solar heat, but only one had a relative and one a neighbour as an informant. This suggests that the course organizers have an important role in raising awareness of solar heat and the possibility to self-build.

Most self-building course participants took part in the course in order to obtain a solar heat collector for their own property $^{3}$ (Figure 1). Another common reason to participate was a general desire to learn more about solar heat. Many of the participants were also spurred by the opportunity to gain a solar heat collector cheaply by making it themselves. Almost half also indicated a desire to learn about heating systems and the installation of solar panels within existing systems. This reflects our findings at Eurajoki: there were several participants who were more oriented towards learning and had no specific idea of how to make use of the collector(s) they were building. Less frequently indicated reasons in the survey were the enjoyment of doing crafts. Concerns for climate change and carbon footprints were mentioned by less than one-third of the participants. Only about $10 \%$ had some kind of professional interest in participating in the course, and there were very few who had enrolled in

Table 2. Characteristics of survey respondents $(n=134)$.

\begin{tabular}{|l|c|}
\hline Average age, years & 58 \\
\hline Share of men, \% & 92 \\
\hline Occupation related to building systems, share \% & 27 \\
\hline Share living in detached houses, \% $\%$ & 84 \\
\hline Share of pensioners, $\%$ & 44 \\
\hline Share having participated in previous DIY course, \% & 59 \\
\hline Share having participated in local politics, \% & 79 \\
\hline Share having planned to install a solar heat collector in own property, \% & 53 \\
\hline Share having background knowledge before enrolling in the course, \% & 16 \\
\hline Share having acquainted themselves with existing solar installations, $\%$ & 13 \\
\hline
\end{tabular}




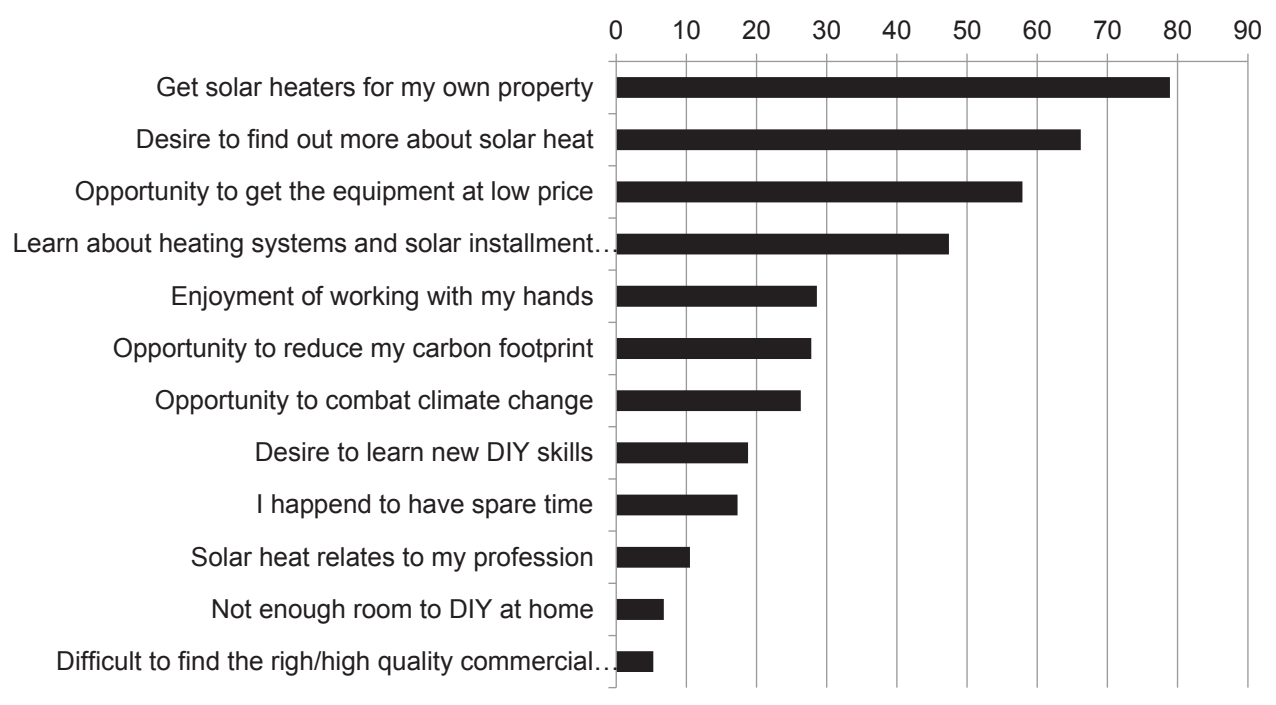

Figure 1. Motives and reasons to participate in solar heat self-building courses $(n=134)$.

the course because of a lack of suitable commercial alternatives.

According to the survey, the course participants' interests appear to be pragmatic and relate to the content of the course rather than a general interest in crafts. Self-building and an explicit desire to get materially engaged do not appear to be the main reason for participants to enrol. Nor do the courses seem to primarily be a way to spend one's spare time. However, when observing the participants working at the Eurajoki course, it was obvious that people were enjoying the material engagement, keen to discuss the best methods of assembly, and also quick to develop suggestions for improved design. Participants were skilled and fluent in the required tasks, but clearly oriented towards solar heat collectors as an outcome of the activity and as an item to discuss while working. Moreover, in our survey, $90 \%$ of the course participants reported that they enjoyed the company of other course participants - even though only $38 \%$ expected to keep in touch with other participants after the course.

\section{Outcomes and Impacts of Self-Building Courses}

One of the expected outcomes of participation in a solar heat collector selfbuilding course is the material product, the solar heat collector. Hence, courses may contribute to the diffusion of solar heat collectors, providing the heat collectors are subsequently installed and put to use. We found that only $41 \%$ had installed their solar heat collectors. There were multiple reasons for this, ranging from other uncompleted building projects, the need to obtain a new boiler, to simply a lack of time and, frequently, money. Many were still planning to install their solar heat collector one day. This delay resonates with the findings that many participants had done little planning beforehand and found out about the course in a less deliberate way. Among those who had installed their solar heat collectors, $85 \%$ were satisfied with their performance. Their satisfaction was also usually well-grounded, as three-fourths of these participants monitored the performance of their collector at least weekly. 
However, previous literature suggests that participation in solar self-building courses might have broader outcomes than merely the accomplishment of a piece of equipment (Darby, 2006; Rohracher \& Ornetzeder, 2006). The experiences from the Eurajoki course were encouraging: without a systematic interview of all the previous years' participants, we came across two active carriers of the solar heat agenda. One of them had begun to develop tools for the assembly process and the other had given presentations of his solar heating system in his local community. On the course in 2012, we also encountered a professional metal worker who was pondering about starting production activities after the course. With such positive hints, we hence explored a range of potential outcomes in our survey questions (Figure 2).

Ornetzeder and Rohraher (2006) discuss the way in which solar heat collector self- building courses have served to socially embed new technologies in several rural contexts. The visibility of solar heat collectors appearing on roofs in each village where selfbuilding courses were organized enhanced the diffusion of solar heat in these localities. Hence, we were interested in finding out how many of the solar heat collectors were installed and the amount of attention they received by neighbours. According to the survey, as many as $59 \%$ had discussed solar heating with their neighbours. This share was even higher, $89 \%$, among those who had installed their heat collector. Some of the teachers we interviewed also believed that their course activities have made a small but visible impact on the diffusion of solar heat in the course localities. A surprisingly large number, $47 \%$, also reported having given others advice on or planned solar installations for other people.

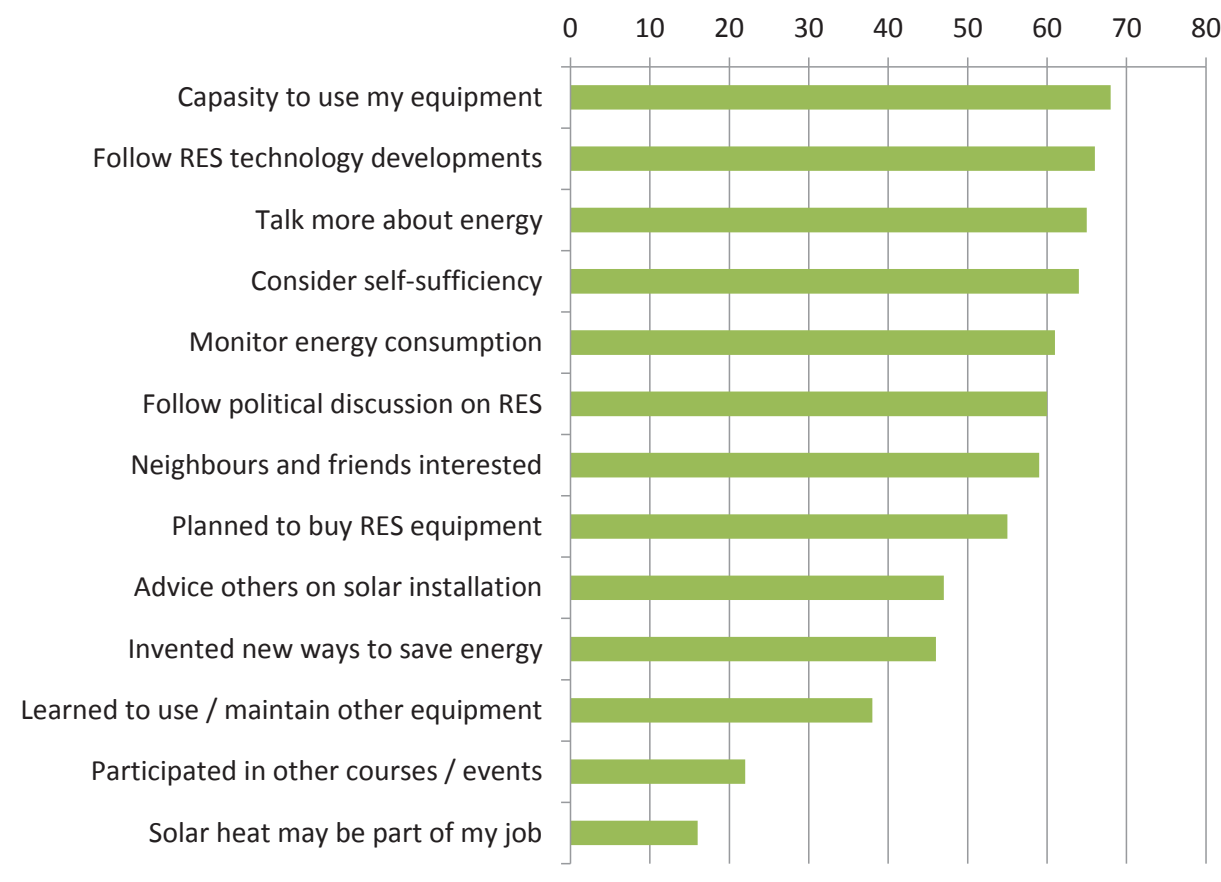

Figure 2. Outcomes of the courses experienced by course participants (\%) $(n=134)$. 
Darby (2006) has examined the role of self-building activities in constructing awareness of energy issues via engagement in concrete activities and the development of tacit knowledge (i.e., skills based on personal experience). In a survey of participants in an energy-conscious village competition, she found that people with more self-building experience implemented a larger number of the actions proposed in the competition, and those who had implemented measures were more capable of processing explicit (i.e., expert-generated) knowledge. She suggests that as tacit knowledge accumulates, people become more capable of seeking out new explicit knowledge as needed, inventing solutions to problems, and sharing knowledge with others. This inspired us to ask people about changes in their energy consumption practices and engagement in other forms of energy activism.

In terms of tacit knowledge and overall energy management competences, the courses seem to have influenced a large share of the participants. Two-thirds had at least gained the capability to use their own equipment. Broader impacts were also visible: Many had started to consider the possibility of comprehensive energy selfsufficiency. A large majority had started to monitor their energy consumption more closely and about $45 \%$ had invented new ways to save energy.

The majority also had plans to make further investments in renewable energy solutions. Almost two-thirds of the participants also followed renewable energy technology developments more closely after the course, and a similar number of participants had started to talk more about energy with other people. The majority of the participants were inspired by the course to follow political debates on energy more closely than before.

We can take Darby's (2006) argument even somewhat further. For many lay people, formal energy efficiency knowledge is very confusing because of the unfamiliar technical terminology employed (Parnell \& Popovics-Larsen, 2005) and because of the historical disenfranchisement of lay people from centralized systems of energy production (van Vliet et al., 2005). Selfbuilding courses might help people to overcome such obstacles and gain a more active and empowered relation to energy technologies. In very concrete terms, the courses offer opportunities and ample time to begin to talk about energy with likeminded fellow-participants and to collect ideas and knowledge about energy related issues while involved in familiar assembly tasks. The course context - a well-trialled, simple collector design and a group of people in which skills can be pooled seems to offer an easy, successful entry to the realm of renewable energy production.

The fact that more than two-thirds of our course participants had started talking about energy consumption more than previously suggests that they have been somehow empowered to also deal with energy issues in more explicit, verbal terms. Perhaps the fact that they are also following energy technology and policy developments suggests a similar phenomenon, as well as the widely endorsed bold ideas about energy self-sufficiency. However, contrary to our expectations, the effect of empowering participants was not any stronger on the people with no background in building systems or energy relates issues; in fact, the building professionals had become slightly more eager to discuss energy issues than the lay people had ${ }^{4}$.

We made a closer analysis of the relation between people's background knowledge on solar heat before the course $\mathrm{e}^{5}$ and the impacts of the course. Overall, it seems that if there were differences between participants with different levels of background knowledge, these were in favour of those with greater background knowledge: 
- Those who had acquaintance of an installed system before the course had more frequently (94\%) gained sufficient knowledge to use and maintain their own equipment than those who had no prior acquaintance of such systems (74\%).

- Moreover, those who had acquaintance of an installed system before the course had more frequently (82\%) started to monitor their own consumption than those who had no prior acquaintance with solar heat collectors $(66 \%)$.

These findings suggest that the course is not the only source of empowerment but previous knowledge and experience matter. However, both those with previous experience and those with none benefited from the course. For example, even among those who had no background knowledge of solar heat before the course, as many as $54 \%$ had advised or helped others in their own solar installations (compared with $50 \%$ of those who prior acquaintance with solar heat collectors).

We might also explore links between DIY as a hobby, and future occupational orientations or aspirations (Holthgrewe \& Werle, 2001). Several of the course participants we surveyed had occupations (or had retired from former occupations) that were somehow linked to building, construction or building components or equipment. Moreover, we found a minority of $15 \%$ agreeing that "solar self-building competences might be a part of my future career". Interestingly, in the Eurajoki course, a few participants had decided to join the course because they had seen solar heat collectors in construction projects for clients. Hence, while conclusive evidence is still pending, our data suggest that also the pathways of solar technology diffusion can be quite complex, and self-building can be linked in various ways to diffusion via commercial or occupational channels.

\section{Discussion}

The empirical material that we draw on is somewhat scattered. However, in terms of the outcomes of the courses, our interviews with teachers, observation of course participants and the survey complement each other. Concerning the survey, we point to particular difficulties relating to the interpretation of the results. Firstly, there have been two quite different course concepts in Finland with likely differences also in terms of the types of discussions and thought processes stimulated among participants. It seems reasonable to think that the longer courses have a greater impact on the participants' overall energy awareness, apart from the immediate goal of constructing solar collectors. Secondly, the timespan between the survey and the actual participation varies from couple of months to approximately 10 years which evidently creates difficulties for analysing the effects of the course. In all cases, it is difficult to disentangle the effect of the course from other developments. Motivations to enter the course, the course itself and the activities thereafter form a continuum that is affected by many other factors as well.

Our two first research questions address Finnish solar heat self-building courses as a continuum of the success of Austrian courses (Ornetzeder, 2001; Ornetzeder \& Rochracher, 2006). Our first question was whether the phenomenon has the capacity to survive in a different cultural context. The related second question that we posed is whether the Finnish courses can be seen as a collective phenomenon with the capacity to reproduce and grow.

The Finnish self-building courses differ significantly from their Austrian rolemodels albeit explicit effort was made 
to import the model into Finland. Quite crucially, educational institutions play a key role in pulling a group of participants together. Unlike in Austria, the participants in the Finnish courses do not know each other and the commitment to the collective building effort only emerges once the course starts. Furthermore, Ornetzeder (2001) reports that theory, planning and dimensioning precedes the Austrian courses hence situating course in a much more determined process of adopting solar heat. Finnish courses, on the other hand, appear as the first and often even quite haphazard instances of encountering and familiarizing oneself with solar heat. Furthermore, Finnish courses have depended on few key individuals who are professionally engaged in providing parts and teaching the courses. Altogether Austrian and Finnish courses depend on a quite different logic albeit the key technology of the simple flat plate collector is shared by the two contexts.

This difference has implications in terms of the momentum and the replication of the courses. Who could be the carriers of course activity and actively contribute to the expansion of the volume of these courses? This far, the teachers and the institutions that facilitate the courses seem not to coordinate their activities, nor to share resources or hold a collective identity. Neither does the national association of solar energy promote self-building or the courses in any explicit way. Moreover, albeit $38 \%$ of participants reported that they expect to keep in touch with others, our interviews with teachers and course organisers do not give signs of a collective mobilization. In other words, in Finland solar heat seems to lack the key ingredients of a social movement, and the potential for the extension and replication of course activity is limited at least when compared with Austrian experiences.

Our research question 3 and 4 address the impacts of these courses in terms of creating acceptance for solar thermal technology and a more active stance toward energy in general. Regarding the third question, the Finnish courses seem quite effective in promoting acceptance and local embedding of solar heat. The threshold to get involved in solar heat through selfbuilding courses seems low: participants enrol with only very preliminary interest and knowledge about solar heat, and are also driven by DIY motives. Based on our field observation, they begin to talk about energy issues and rehearse their skills during the course while being materially engaged and conducting rather simple tasks of assembly. Empowerment seems to result out of successful accomplishment of material tasks in renewable energy and from the ability to address these technologies in a way that is meaningful in the peer group. Renewable energy is not only doable, it might even be enjoyable. Meanwhile, participants' capacity to formalize and distribute knowledge also increases: the survey results indicate that a significant share of participants also continue to collect and disseminate information about renewable energy technologies. Thus, even if the courses and participants lack social organization and collective momentum in promoting solar heat technology, many course participants seem to act as carriers of this technology on their own.

User involvement and self-building activities have been related to social movements for alternative energy technology (Jamison, 2001; Ornetzeder, 2001). While the course participants' motives to enrol in the course were not explicitly political, the courses appear to lead participants into taking a more active and political role (cf. Marres, 2009). We reported active opposition of centralized energy systems and state involvement in distributed energy systems during field observation. In the survey, this is reflected in the large share of respondents reporting to have started to consider far-reaching 
energy self-sufficiency. The survey also reports broader political interest as a result of course participation.

In response to the fourth question, we argue that participants gain significantly more than the single piece of equipment as a result of the course. Many have started to follow their energy consumption and report to have invented new ways to save energy at their home. Participants' interests in energy self-sufficiency suggest that the course is part of a trajectory towards adopting other renewable energy technologies. Overall, the fact that many collectors are installed with delay and some remain uninstalled is only part of the story. Gains in tacit knowledge and an active orientation towards using renewable energy sources do not require that collectors are installed. As we reported, participants have started to advise and plan installations for others even if they have not installed their own equipment. However, much to our surprise, it is not those who had the least background who report the most significant impacts in this respect. Rather, those with some professional overlap with solar heat are the ones who seem to pick up the most momentum to continue to discuss and work on solar heat and other energy related issues.

\section{Conclusions}

Climate change mitigation and a transition towards low carbon energy systems are increasingly visible and important policy objectives. However, in this agenda, ordinary citizens have mainly been assumed to take up a role of passive receiver of novel technologies. Yet, studies of user involvement in technology development and adoption make it obvious that users can have a far more active role in technology dissemination. Equally obviously, outside the deep-green marginal groups, the motives to get involved align with a mix of more or less private concerns.
Our interest in the self-building courses for solar heat collectors initially arose from the thought that these courses might reveal something interesting about the mixed motives for getting involved in domestic low carbon technologies. Recognizing the Austrian experiences we also thought that these courses might be a feasible avenue for public promotion of low carbon technologies. To put the issue another way, we were interested in what kinds of motives, and more generally paths and backgrounds, drove people to participate in these courses, and whether such motives could be made use of more widely to support the diffusion of renewable energy technologies and energy saving. Previously, solar heat collector self-building courses have been assessed from the point view of the nationwide diffusion of solar water heat collectors (Ornetzeder, 2001) and that of user-led innovation (Ornetzeder \& Rohracher, 2006). However, the role that courses play in disseminating general energy awareness and particularly in engaging citizens in practical work for energy efficiency and climate change mitigation goes beyond their role in technology development and deployment.

The courses proved effective in drawing people into solar heat technology even with little background knowledge and specific ideas about how to put the built collectors to use. The same phenomenon is also reflected in the fact that we found frequent delays in installing the collectors and unanticipated budget limitations. This is, we argue, however not much of a failure. Rather, a plausible interpretation is that selfbuilding courses represent a low-threshold first step toward more demanding changes towards renewable and more self-sufficient energy systems. The pathways through which individuals become involved in selfbuilding activities are nevertheless complex: our results indicate that background knowledge in building technology prompts 
higher levels of active engagement after the course. However, here we run into the limits of quantitative analysis in trying to understand engagement processes.

The Finnish courses proved a more extensive phenomenon than what we had expected. We came across over 700 course participants during a period that starts from the early 2000s. This number is far from insignificant when compared with the low number of solar collectors in Finland in general. However, we also came to the conclusion that self-building activity in Finland has depended on a few key teachers and the folk high schools and lacks institutional support. This limits the potential replication of the course concept. The difference compared to the Austrian example is clear. Ornetzeder (2001) reports the success of Austrian self-building groups that made use of collective resources and knowledge whereas we have found in Finland self-building courses that depend on initiatives from outside the group of course participants. Notwithstanding this difference, the Finnish courses seem to offer alternative ways to get people involved with low carbon technology and promote local acceptance and embedding of this technology. They also seem to set trajectories for processing and adopting more formal knowledge about energy. We hence suggest that they are a promising route for further experimentation in public policies promoting distributed energy generation.

\section{Acknowledgements}

This research has been supported by the Academy of Finland grant (140938 and 140906).

\section{References}

Bijker, W. E., Hughes, T.P. \& T.J. Pinch (1987) The Social Construction of Technological Systems: New Directions in the Sociology and History of Technology (Cambridge, MA: MIT Press).

Darby, S. (2006) 'Social learning, household energy practice and public policy: lessons from an energy-conscious village,' Energy Policy 34(17): 2929-2940.

ESTIF (2012) Solar Thermal Markets in Europe - Trends and Market Statistics 2011. European Solar Thermal Industry Federation. Online: http://www.estif.org/ statistics/st_markets_in_europe_2011/.

Faninger-Lund, F. \& P. Lund (2000) Aurinkolämmön itserakentamisopas [Guide for self-building of solar heat, in Finnish] (Helsinki: Motiva).

Freeman, S. (2007) 'The Material and Social Dynamics of Motivation: Contributions to Open Source Language Technology Development', Science Studies 20(2): 5577.

Heiskanen, E. (2005) 'Taming the Golem - An Experiment in Participatory and Constructive Technology Assessment', Science Studies 18(1): 52-74.

Hoffman, S.M. \& A. High-Pippert (2005) 'Community Energy: A Social Architecture for an Alternative Energy Future', Bulletin of Science, Technology \& Society 25(5): 387-401.

Holthgrewe, U. \& R. Werle (2005) 'DeCommodifying Software? Open Source Software Between Business Strategy and Social Movement', Science Studies 14(2): 43-65.

Hyysalo, S., J.K. Juntunen \& S. Freeman (2013) 'Internet Forums and the Rise of the Inventive Energy User,' Science \& Technology Studies 26(1): 25-51. 
Jamison, A. (2001) The Making of Green Knowledge. Environmental Politics and Cultural Transformation (Cambridge: Cambridge University Press).

Lindström, D. (2006) Aurinkolämmön rakentamisen opaskirja [Guidebook for building solar heat, in Finnish] (Vaasa: Svenska Yrkehögskolan).

Marres, N. (2009) 'Testing powers of engagement: green living experiments, the ontological turn and the undoability of involvement', European Journal of Social Theory 12(1): 117-133.

Marres, N. \& J. Lezaun (2011) 'Material and devices of the public: an introduction', Economic and Society 40(4): 489-509.

Ornetzeder, M. (2001) 'Old technology and social innovations. Inside the Austrian success story on solar water heaters,' Technology Analysis \& Strategic Management 13(1): 105-115.

Ornetzeder M. \& H. Rohracher (2006) 'User-led Innovations and Participation Processes: Lessons from Sustainable Energy Technologies', Energy Policy 34(2): 138-150.

Palm, J. \& M. Tengvard (2011) 'Motives for and barriers to household adoption of small-scale production of electricity: examples from Sweden', Sustainability: Science, Practice and Policy 7(1): 6-15.

Parnell, R. \& O. Popovics-Larsen (2005) 'Informing the Development of Domestic Energy Efficiency Initiatives. An Everyday Householder-Centred Perspective,' Environment and Behaviour 37(6): 787807.

Raven, R.P.J.M., E. Heiskanen, R. Lovio, M. Hodson \& B. Brohmann (2008) 'The contribution of local experiments and negotiation processes to fieldlevel learning in emerging (niche) technologies: meta-analysis of 27 new energy projects in Europe', Bulletin of Science Technology Society 28(6): 464477.
Rip, A., T.J. Misa \& J. Schot (1995) Managing Technology in Society. The Approach of Constructive Technology Assessment (London \& New York: Pinter Publishers).

Schot, J.W. (2001) 'Towards New Forms of Participatory Technology Development' Technology Analysis and Strategic Management 13(1): 39-52.

Van Vliet, B., Chappells, H. \& E. Shove (2005) Infrastructures of Consumption. Environmental Innovation in the Utility Industries (London: Earthscan).

von Hippel, E. (2005) Democratizing innovation (Cambridge, MA: MIT Press).

Watson, M. \& E. Shove (2008) 'Product, Competence, Project and Practice DIY and the Dynamics of Craft Consumption, Journal of Consumer Culture 8(1): 69-89. Wolf, M., \& S. McQuitty (2011) 'Understanding the do-it-yourself consumer: DIY motivations and outcomes', AMS Review 1 (3-4): 154-170.

\section{Notes}

1 see e.g. http://www.24volt.eu/eng home.php and http://www.scoraigwind. com/

2 All data presented here pertain to the time of responding to the survey. Since the participants may have attended the course as early as the 1990s (and one participant indicated he took part in 1974), the characteristics do not necessarily reflect the situation when taking the course.

3 Not all courses were strictly self-building courses in the sense that each participant made a solar heat collector for themselves. Of our respondents, $90 \%$ had participated in a self-building course.

4 The share is $80 \%$ for the building professionals and $71 \%$ for those without any background in building (Pearsons Chi square Sigma 0,318 (2-sided)). 
5 This set of questions pertained to whether they had collected information on solar thermal products in the market, had familiarized themselves with actual installed solar thermal systems, or had knowledge of the general principles of solar heat, or had planned to install a heat collector in their own property.
Mikko Jalas

Aalto University

Department of Management Studies

Lapuankatu 2, 00100 Helsinki, Finland mikko.jalas@aalto.fi

Helka Kuusi

National Consumer Research Centre Kaikukatu 3, 00531 Helsinki, Finland helka.kuusi@ncrc.fi

Eva Heiskanen

National Consumer Research Centre Kaikukatu 3, 00531 Helsinki, Finland eva.heiskanen@ncrc.fi 